\title{
Anatomical variations in scapes of Eleocharis minima Kunth (Cyperaceae, Poales) - amphibian and Kranz species
}

\author{
Shirley Martins ${ }^{1,3}$ \& Vera Lucia Scatena ${ }^{2}$
}

\begin{abstract}
In Cyperaceae about 1/3 of the species have Kranz anatomy and some species of Eleocharis can either present Kranz anatomy or not according to the environmental conditions, whether terrestrial (emerged) or aquatic (partly or fully submerged). Eleocharis minima has emerged and submerged scapes in the same individual. To identify the possible differences and their correlation with the environment, the anatomy of these scapes was investigated. The emerged scape is quadrangular e has four vascular bundles, and the submerged is triangular with three bundles. Both scapes (emerged and submerged) show non-Kranz anatomy in the basal region and Kranz anatomy of the eleocharoid type in the median region. In the apical region of submerged scapes occur Kranz anatomy of eleocharoid types, but in this same region of the emerged scape was observed variations in the continuity of the inner bundle sheath and may be interpreted as eleocharoid or chlorocyperoid types. The plasticity of the Kranz anatomy in Eleocharis minima and in other species of the genus is probably related to the amphibious habit. Therefore, the use of characters related to Kranz anatomy in Eleocharis in phylogenetic and evolutionary approaches should be restricted and carefully analyzed in view of its plasticity.
\end{abstract}

Key words: plasticity, Kranz anatomy, Eleocharis, aquatic macrophytes, photosynthesis $\mathrm{C}_{4}$.

\section{Introduction}

Cyperaceae has 45 genera, of which 28 present Kranz anatomy that is related to $\mathrm{C}_{4}$ photosynthesis (Bruhl \& Wilson 2007). In the family, only Cyperus, Eleocharis, Fimbristylis and Rhynchospora contain Kranz and non-Kranz species (Soros \& Bruhl 2000; Bruhl \& Wilson 2007). Eleocharis has approximately 250 species (Govaert et al. 2007), and 20 of them were described as having Kranz anatomy (Bruhl \& Wilson 2007). The species of the Eleocharis genus occur in environments with moist or flooded soil, and the plants may be partially or totally submerged (Trevisan \& Boldrini 2008). These plants are characterized by a leaf lamina reduced to a tubular sheath that is located in the base of the scape, which is the principal photosynthetic organ (Hinchliff et al. 2010; Roalson et al. 2010).

As observed in Eleocharis baldwinii (Torr.) Chapm., E. retroflexa (Poir.) Urb. and E. vivipara Link., the Eleocharis stand out in Cyperaceae by the plasticity of having or not having Kranz anatomy in different individuals as a response to environmental conditions (Uchino et al. 1998; Murphy et al. 2007). These species present Kranz anatomy $\left(\mathrm{C}_{4}\right)$ when they are terrestrial and nonKranz anatomy $\left(\mathrm{C}_{3}\right)$ or a $\mathrm{C}_{3}-\mathrm{C}_{4}$ intermediate when they are submerged (Uchino et al. 1998; Ueno 2004; Murphy et al. 2007).

In addition to the variable presence of Kranz anatomy, different Kranz types were observed in Eleocharis vivipara individuals from distinct populations (Murphy et al. 2007). To date, the plasticity of Kranz anatomy in Eleocharis has only been described in different individuals growing in distinct environmental conditions, either terrestrial or submerged. Therefore, because Eleocharis minima Kunth, which performs $\mathrm{C}_{4}$ photosynthesis (Bruhl \& Wilson 2007), presents both emerged and submerged scapes in the same individual, this work aimed to study the anatomy of these scapes and to identify the possible differences that can be correlated with environmental conditions.

\footnotetext{
${ }^{1}$ Universidade Estadual do Oeste do Paraná (UNIOESTE), Centro de Ciências Biológicas e da Saúde, R. Universitária, Jardim Universitário, 85819-110, C.P. 000711, Cascavel, PR, Brazil.

${ }^{2}$ Universidade Estadual Paulista (UNESP), Inst. Biociências, Depto. Botânica, 13506-900, Rio Claro, SP, Brazil.

${ }^{3}$ Author for correspondence: shirley_botany@yahoo.com.br
} 


\section{Materials and Methods}

Individuals of Eleocharis minima from different populations (S. Martins 405, 406, 423) occurring in lakes margins from the southern Brazil were collected. Vouchers materials were deposited at the Herbarium of the Department of Botany, Universidade Estadual Paulista (HRCB). The individuals collected were fixed in FAA 50 and stored in $70 \%$ ethanol (Johansen 1940). The analyses were realized in mature emerged and submerged scapes of the same individual each from the three different populations.

Portions of the emerged and submerged scapes were dehydrated in an ethyl alcohol series and then embedded in Historesin (Leica Historesin Embedding Kit, Nussloch, Germany) (Feder \& O'Brien 1968). Transverse sections of the basal, median and apical regions were made using a microtome, stained with periodic acid-Schiff's reagent and toluidine blue (Feder \& O'Brien 1968) and mounted in Entellan (Merck). Transverse sections of the basal, median and apical regions of mature scapes were also made by hand, stained with basic fuchsin and Astra blue (Roeser 1972) and mounted in glycerin jelly. Counting of number of fiber strands and cells that they have was done in different transverse sections. The terminology about the vascular bundle sheaths is in accord to ontogenetic studies realized by Martins and Scatena (2011). The images were obtained with Leica DFC 290 digital camera clopped to the Leica DM LB microscope using the IM50 software.

\section{Results}

Eleocharis minima is herbaceous, perennial and cespitous (Fig. 1a), with scapes that are approximately $10 \mathrm{~cm}$ high and present photosynthetic emerged (Em) (Fig. 1b) and submerged (Sb) (Fig. 1b-c) forms. In transverse section, the emerged scape is quadrangular, with four vascular bundles (Fig. 1d), and the submerged scape is triangular, with three vascular bundles (Fig. 1e).

Both scapes have a uniseriate epidermis (Fig. $1 \mathrm{f}-\mathrm{k}$ ) with thin-walled cells in the basal region of the emerged scape (Fig. 1f) and thick-walled cells other of the emerged scape and of all of the regions of the submerged (Fig. 1g-k). Below the epidermis, fibers (Fi) occur in general isolated in the basal region of submerged and emerged scapes (Fig. 1f, i) or in strands in the others regions, mainly in the emerged scapes (Fig. 1g-h). The epidermal cells associated to the fibers are papillose (Fig. 1i, detail) and have conical silica bodies (Si) (Fig. 1g, i).

The chlorophyllian parenchyma is composed of one layer of cells in the basal region of the emerged scape (Fig. 1f), of two layers in the other regions of the emerged scape and of all of the regions of the submerged scape (Fig. 1i-k). In the inner layer of the regions with two layers, the cells are arranged radially around the vascular bundles (Fig. 1g-k, asterisk). Idioblasts containing phenolic compounds are present in the chlorophyllian parenchyma (Fig. 1f-k).

The scapes possess vascular bundles of different calibers. One major, one intermediate and two small bundles occur in the emerged scapes (Fig. 1d), whereas one major and two small bundles occur in the submerged scapes (Fig. 1e). The emerged scape in the basal region exhibits non-Kranz anatomy, and the vascular bundles are surrounded by a double sheath: the outer layer presents thin-walled cells with a few chloroplasts, constituting the endodermis (Fig. 1f, circles); and the inner layer presents thick-walled cells without chloroplasts, constituting the pericycle (P) (Fig. 1f). The median region of both scapes (emerged and submerged - Fig. 1g, j) and the apical region of the submerged scapes (Fig. 1k) present Kranz anatomy with vascular bundles surrounded by two continuous bundle sheaths: the outer one presents thick-walled cells without chloroplasts, and the inner one presents thin-walled cells with chloroplasts (Fig. 1g, j), both constituting the biseriate pericycle (P). In the basal region of the submerged scape the vascular bundles present two sheaths: the outer one is continuous, lacks chloroplasts and possess thickwalled cells and the inner one is discontinuous, has few chloroplasts and present thin-walled cells (Fig. 1i). In the apical region of the emerged scape also occur Kranz anatomy, but the continuity of the inner bundle sheath varies among the populations, being continuous or discontinuous (Fig. 1i). Aerenchyma (Ae) occurs in the basal and median regions of the emerged scapes (Fig. 1d) and in all of the regions of the submerged scapes (Fig. 1e) internally to the chlorophyllian parenchyma.

\section{Discussion}

According to our results, the anatomical differences found between the emerged and submerged scapes of Eleocharis minima suggest a revision of the species characterization that has been described only with regard to quadrangular 

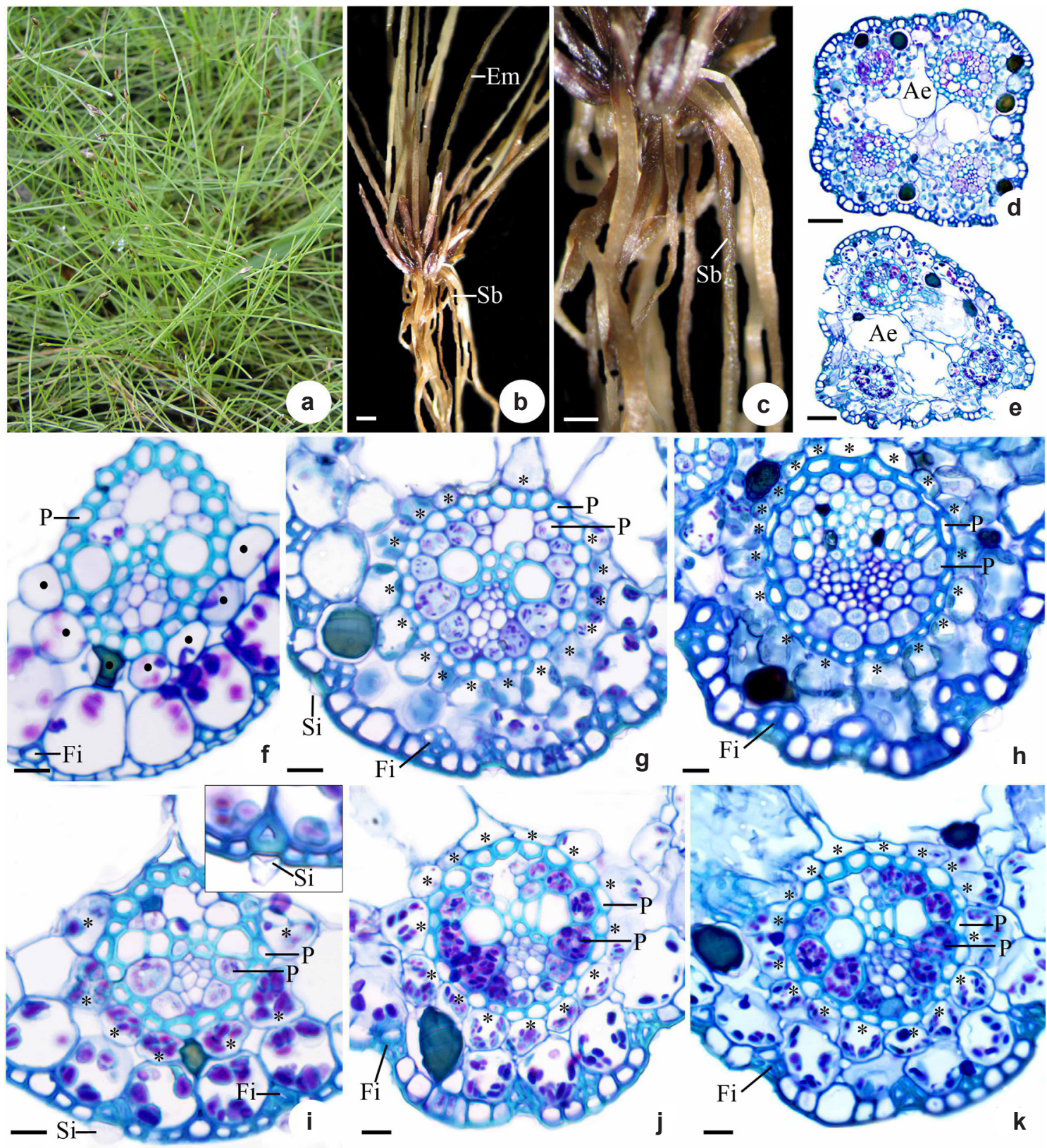

Figure 1-Morphological and anatomical aspects of emerged and submerged scapes of Eleocharis minima Kunth. a-c. morphological aspects - a. habit; b. mature plants with emerged $(\mathrm{Em})$ and submerged $(\mathrm{Sb})$ scapes (bar $=4 \mathrm{~cm}) ; \mathrm{c}$. mature plant detaching submerged scape $(\mathrm{Sb})(\mathrm{bar}=2 \mathrm{~cm}) ; \mathrm{d}-\mathrm{k}$. anatomical aspects $-\mathrm{d}$-e. general view of the median regions of emerged and submerged scapes, respectively $(\mathrm{bar}=30 \mu \mathrm{m})$; $\mathrm{f}-\mathrm{h}$. detail of the basal, median and apical regions of the emerged scape, respectively $(\mathrm{bar}=10 \mu \mathrm{m})$; $\mathrm{i}-\mathrm{k}$. detail of the basal, median and apical regions of the submerged scape, respectively $(\mathrm{bar}=10 \mu \mathrm{m})(\mathrm{Ae}$, aerenchyma; asterisks, radiate parenchyma cells; circles, endodermis; Em, emerged scape; Fi, fibers; P, pericycle; Sb, submerged scape; Si, silica bodies).

scapes (Trevisan \& Boldrini 2008). The submerged scapes are more filamentous than are the emerged scapes; probably due to fewer vascular bundles and cells in the fiber strands, which are both adaptive responses to the amphibious life form (Coan et al.
2002). The presence of aerenchyma and the reduced number of vascular bundles and support tissues is common in aquatic plants (Coan et al. 2002; Maberly \& Madsen 2002), including Eleocharis species (Ueno 1996, 2004). These hydromorphic 
features of the submerged scapes of Eleocharis minima can help the plant fluctuate, favoring its growth in an environment with variations in the water level.

The occurrence of $\mathrm{C}_{4}$ photosynthesis in aquatic macrophytes, as in Eleocharis minima, is indicated in response to bright light conditions and low levels of free $\mathrm{CO}_{2}$, which in the latter case is due to the high photosynthetic rate of algae (Bowes et al. 2002; Sage 2004).

The continuity of the inner sheath in major vascular bundles of Kranz Cyperaceae species is one of the criteria used to classify the Kranz types (Soros \& Bruhl 2000; Martins \& Scatena 2011). The chlorocyperoid and eleocharoid only differs on this criterion, since both possess two bundle sheaths. Therefore, this is the first report of vascular bundles with continuous and discontinuous inner sheath in different scapes from the same species.

Most of the Kranz species in Eleocharis present the eleocharoid type, but the fimbristyloid type also occurs in Eleocharis baldwinii and the eleocharoid and fimbristyloid types occur in individuals from different populations of Eleocharis vivipara (Ueno 1996; Murphy et al. 2007). These two types of Kranz anatomy differ from each other in the number of bundle sheaths, with two in the eleocharoid and three in the fimbristyloid; and in the continuity of the inner bundle sheath, being continuous in the eleocharoid and discontinuous in the fimbristyloid (Soros \& Dengler 2001).

In Eleocharis minima, the median and apical regions of the submerged scapes possess Kranz anatomy, as characterized by the presence of many chloroplasts in the inner bundle sheath. In another species of Eleocharis, differences in the type of Kranz anatomy and in the photosynthetic metabolism in response to environmental conditions were verified as being related to the availability of water in the soil (Ueno et al. 1989; Uchino et al. 1998; Ueno 2004). In these species, which are considered facultative $\mathrm{C}_{3}-\mathrm{C}_{4}$, the terrestrial individuals present Kranz anatomy, and the submerged individuals present non-Kranz anatomy or Kranz-like anatomy (Murphy et al. 2007). The absence of Kranz anatomy in the basal region of the emerged and submerged scapes can be related to the occurrence of leaf sheaths in this region, which probably reduces the photosynthetic activity in this area of the scape.
The variations observed in the occurrence of the Kranz anatomy and in inner bundle sheath continuity in emerged and submerged scapes of Eleocharis minima reinforce the anatomical plasticity of the genus. But, we believe that this variation is not sufficient to indicate the occurrence of different Kranz types to Eleocharis minima. In the angiosperm groups with $\mathrm{C}_{4}$ photosynthesis, including in Cyperaceae, the presence and the type of Kranz anatomy are important for phylogenetic studies (Soros \& Bruhl 2000; Giussani et al. 2001; Muhaidat et al. 2007). However, due to the plasticity of the Kranz anatomy found in Eleocharis minima and in others Kranz Eleocharis species, we suggest that these characters can only be consistent in the phylogeny of the terrestrial species.

\section{Acknowledgements}

We thank the Fundação de Amparo à Pesquisa do Estado de São Paulo - FAPESP for a PhD grant (2008/09380-2) to S. Martins and financial support (2011/18275-0) and the Conselho Nacional de Desenvolvimento Científico e Tecnológico - CNPq for financial support to V. L. Scatena (301692/2010-6 and 471837/2011-3).

\section{References}

Bowes, G.; Rao, S.K.; Estavillo, G.M. \& Reisking, J.B. 2002. $\mathrm{C}_{4}$ mechanisms in aquatic angiosperms: comparisons with terrestrial $\mathrm{C}_{4}$ system. Functional Plant Biology 29: 379-392.

Bruhl, J.J. \& Wilson, K.L. 2007. Towards a comprehensive survey of $\mathrm{C}_{3}$ and $\mathrm{C}_{4}$ photosynthetic pathways in Cyperaceae. In: Columbus, J.T., Friar, E.A., Hamilton, C.W., Porter, J.M., Prince, L.M. \& Simpson, M.G. (eds.). Monocots: comparative biology and evolution. Rancho Santa Ana Botanic Garden, Claremont. Pp. 99-148.

Coan, A.I.; Scatena, V.L. \& Giulietti, A.M. 2002. Anatomia de algumas espécies aquáticas de Eriocaulaceae brasileiras. Acta Botanica Brasilica 16: 371-384.

Feder, N. \& O'Brien, T.P. 1968. Plant microtechnique: some principles and new methods. American Journal of Botany 55: 123-142.

Giussani, M.G.; Cota-Sánchez, H.; Zuloaga, F.O. \& Kellogg, E.A. 2001. A molecular phylogeny of the Grass subfamily Panicoideae (Poaceae) shows multiple origins of $\mathrm{C}_{4}$ photosynthesis. American Journal of Botany 88: 1993-2012.

Govaerts, R.; Simpson, D.A.; Goetghebeur, P.; Wilson, K.L.; Egorova, T. \& Bruhl, J.J. 2007. World checklist of Cyperaceae. The Board of Trustees of the Royal Botanical Garden, Kew. 780p. 
Hinchliff, C.E.; Lliully, A.E.; Carey, T. \& Roalson, E.H. 2010. The origins of Eleocharis (Cyperaceae) and the status of Websteria, Egleria, and Chillania. Taxon 59: 709-719.

Johansen, D. 1940. Plant microtechnique. McGrawHill Book Co. Inc., New York. 523p.

Maberly, S.C. \& Madsen, T.V. 2002. Aquatic freshwater angiosperm carbon concentrating mechanisms: processes and patterns. Functional Plant Biology 29: 393-405.

Martins, S. \& Scatena, V.L. 2011. Bundle sheath ontogeny in Kranz and non-Kranz species of Cyperaceae (Poales). Australian Journal of Botany 59: 554-562.

Muhaidat, R.; Sage, R.F. \& Dengler, N.G. 2007. Diversity of Kranz anatomy and biochemistry in $\mathrm{C}_{4}$ eudicots. American Journal of Botany 94: 362-381.

Murphy, L.R.; Barroca, J.; Franceschi, V.R.; Lee, R.; Roalson, E.H.; Edwards, G.E. \& Ku, M.S.B. 2007. Diversity and plasticity of $\mathrm{C}_{4}$ photosynthesis in Eleocharis (Cyperaceae). Functional Plant Biology 34: 571-580.

Roalson, E.H.; Hinchliff, C.E.; Trevisan, R. \& Silva, C.R.M. 2010. Phylogenetic relationships in Eleocharis (Cyperaceae): $\mathrm{C}_{4}$ Photosynthesis origins and patterns of diversification in the spikerushes. Systematic Botany 35: 257-271.

Roeser, K.R. 1972. Die nadel der schwarzkiefer - massenprodikt und kunstwerk der nautr. Mikrokosmos 61: 33-36.

Sage, R.F. 2004. The evolution of $\mathrm{C}_{4}$ photosynthesis. New Phytologist 161: 341-370.
Soros, C.L. \& Bruhl, J.J. 2000. Multiple evolutionary origins of $\mathrm{C}_{4}$ photosynthesis in the Cyperaceae. In: Wilson, K.L. \& Morrison, D.A. (eds.), Monocots: systematics and evolution. CSIRO Publishing, Melbourne. Pp. 629-636.

Soros, C.L. \& Dengler, N.G. 2001. Ontogenetic derivation and cell differentiation in photosynthetic tissues of $\mathrm{C}_{3}$ and $\mathrm{C}_{4}$ Cyperaceae. American Journal of Botany 88: 992-1005.

Uchino, A.; Sentoku, N.; Nemoto, K.; Ishii, R.; Samejina, M. \& Matsuoka, M. 1998. C -type gene expression is not directly dependent on Kranz anatomy in an amphibious sedge Eleocharis vivipara Link. The Plant Journal 14: 565-572.

Ueno, O. 1996. Structural characterization of photosynthetic cells in an amphibious sedge, Eleocharis vivipara, in relation to $\mathrm{C}_{3}$ and $\mathrm{C}_{4}$ metabolism. Planta 199: 382-393.

Ueno, O. 2004. Environmental regulation of $\mathrm{C}_{3}$ and $\mathrm{C}_{4}$ differentiation in the amphibious sedge, Eleocharis baldwinii and comparisons with related species. Plant, Cell \& Environment 27: 627-639.

Ueno, O.; Takeda, T. \& Maeda, E. 1989. Distribution and evolution of $\mathrm{C}_{4}$ syndrome in Eleocharis, a sedge group inhabiting wet and aquatic environments, based on culm anatomy and carbon isotope ratios. Annals of Botany 64: 425-438.

Trevisan, R. \& Boldrini, I.I. 2008. O gênero Eleocharis R. Br. (Cyperaceae) no Rio Grande do Sul, Brasil. Revista Brasileira de Biologia 6: 7-67. 